Миодраг Сибиновић

Универзитет у Београду

Филолошки факултет

ivjovmar@gmail.com
УДК 821.163.41.09-1"19":821.161.1.09-1"19"

https://doi.org/10.18485/slavistika.2019.23.1.13

оригинални научни рад примљено 18.03.2019.

прихваћено за штампу 16.05.2019.

\title{
БРАНКО МИЉКОВИЋ У СРПСКОЈ РЕЦЕПЦИЈИ ПОЕЗИЈЕ ВАЛЕРИЈА БРЈУСОВА
}

Истраживачи књижевних и културних обостраних српско-руских веза досад се нису бавили рецепцијом поезије В. Ј. Брјусова у српској књижевности и култури.

Аутор овог чланка је прикупио основне податке и извршио анализу преводилачких и ширих стваралачких дотицаја са Брјусовљевом поезијом истакнутог српског песника друге половине XX века Бранка Миљковића.

Кључне речи: руска књижевност, српска књижевност, српско-руске књижевне и културолошке везе, књижевни превод, интертекст.

Researchers of the literary and cultural Serbian-Russian connections have not addressed the question of the reception of the poetry of V. J. Bryusov in Serbian literature and culture.

The author of this paper has collected the most important data and has analysed the poetic translations and other creative contacts with Bryusov's poetry of the eminent Serbian mid- $20^{\text {th }}$ century poet, Branko Miljković.

Key words: Russian literature, Serbian literature, Serbian-Russian literary and culturological connections, literary translations, intertext.

1.

У периоду од 1921. до 1924. Валериј Брјусов је објавио четири књиге својих песама. У њима је било и немало пригодних стихова које је тражило ново време и покушаја који нису били на уметничком нивоу Брјусовљевих најбољих поетских остварења. Многе песме пригодне садржине и поједностављеног поетског исказа нису се могле допасти низу књижевних зналаца у Русији и, разуме се, руској интелигенцији из постоктобарске дијаспоре. То се негативно одразило у даљој судбини и рецепцији његове поезије, како у СССР тако и у свету.

Али са протоком времена ванкњижевни идеолошки и други чиниоци постепено су губили актуелност. Тако је, нарочито после познатих друштвених промена у самој Русији с краја XX века, покренут низ нових научних истраживања која, уз примену савремене научне методологије, резултирају како уочавањем неких карактеристика, тако и својеврсним кориговањем односа према поетском делу Валерија Брјусова.

2.

Те околности су, по логици ствари, утицале на ток прихватања и упознавања поезије и поетике Валерија Брјусова у српској култури. Тако, рецимо, пошто је 
двема песмама укључен у антологију руске поезије Ристе Одавића 1914, у периоду од 1918. до 1941. у српској култури Брјусовљево име скоро се и не помиње С. Остојић-Сенски 1921. у „Виделу“ објављује свој прозни превод двеју његових песама (Сенке и Сни страсти) и М. М. Пешић у часопису „Мисао“ свој превод песме Напред. У часопису „Мисао“ те године Лав Захаров објављује свој кратки осврт Поезија Валерија Брјусова. К. Тарановски 1927, у обимом невеликој књизи Из руске лирике уз превод двеју песама даје и књижевно-критичку белешку о песнику, а 1938. године Брјусова помиње у чланку о руском симболизму Плаво небо над утопијом, објављеном у Београду (у њизи Живи оквири), Станислав Винавер. У сарајевком часопису „Преглед“, који је, под уредништвом Јована Кршића, излазио у периоду 1937-1941. година, било је речи и о Брјусову као једном од руских симболиста.

До Брјусовљевог повратка на српску књижевну сцену осетније долази тек крајем педесетих и почетком шездесетих година XX века. Занимљива појединост у томе је да је први подстицајни симптом Брјусовљевог повратка била обимна књига београдске издавачке куће „Култура“- објављена 1959. године под насловом Поезија и револуција. Брјусов. Блок. Мајаковски. Она је садржала превод избора релевантних чланака тројице водећих руских песника, са предговором професора руске књижевности и шефа славистичке катедре београдског Филолошког факултета Радована Лалића. Жива Брјусовљева песничка реч, међутим, почела је тих година да се претаче на наш језик и да се стваралачки улива у савремену српску преводну и оригиналну културу захваљујући, пре свега, Бранку Миљковићу.

Кад се говори о рецепцији Брјусова у српској књижевности и култури, међутим, не би ваљало сметнути с ума ни следећи податак: дугогодишњи професор руске књижевности почетка XX века на београдској славистичкој катедри Мила Стојнић у својој књизи Руско-српска књижевна преплитања (Београд, 1994) наводи и један занимљив пример везе песме Јована Дучића Moja nоезија (у потоњим издањима - објављиване под насловом Поезија) са Брјусовљевом песмом с насловом Младом песнику. М. Стојнић констатује да је Дучић „по свом поетском програму, по схватању друштвене функције уметности и њеног односа према стварности формулисаном у песми [...] најближи поетском програму и естетским схватањима руских симболиста, чији је један од најазапаженијих стиховних израза била програмска песма Валерија Јаковљевича Брјусова 'Младом песнику'“ (Стојнић 1994: 92). Додуше, ова леп пример подударности није карактерисан као контактна веза српског и руског песника...

Уз 55 превода Мандељштамових песама у „Просветиној“ књизи Шум време$н a$ из 1962, Бранко Миљковић је током недугог живота у периодици током 1959 и 1960. и у антологији Руска модерна лирика 1961. године објавио 9 својих превода из поезије Валерија Брјусова, 13 из опуса Александра Блока, 5 из поезије Андреја Белог, 15 - Бориса Пастернака и 9 Леонида Мартинова.

Из ових података, међутим, пада у очи следећи књижевноисторијски занимљив детаљ: ако се изузму преводи поезије Мандељштама, а има се на уму чињеница да иза Брјусовљевих 9 објављених превода, стоје још 34 необјављена превода лирских остварења овог песника који су пронађени у његовој рукописној заоставштини (и постхумно објављени у Сабраним делимa) - испоставља се да се Миљковић, осим Мандељштамом, заправо највише бавио Валеријем Брјусовом.

У „Књижевним новинама“ је из Брјусовљеве поезије 18. децембра 1959. објавио своје следеће преводе: Пре зоре, Вечерња гужва и Магла. У часопису Сусрети 1960. штампао је своје преводе овог руског симболисте: Јесење осећање, Код куће, Син земье, Свет електрона и Свет $N$ димензија. Нана Богдановић и Милица Николић су следеће године у антологију Руска модерна лирика укључиле његове преводе Магла, Пре зоре, Свет електрона и Свет $N$ димензија, додавши још и његов нови превод Брјусовљеве песме Духови ватре

Може се поставити питање: зашто је Бранко Миљковић пред очи књижевне јавности из своје песничке радионице изнео само тих девет превода? Да ли иза тога стоји незаинтересованост ондашње књижевне јавности за још превода овог руског симболисте (Лав Захаров обимом невелику књижицу свог превода Брјусовљевих песама Me eum esse тек 1968. године успева да објави у крушевачкој „Багдали“)? Да ли је узрок био Миљковићева изненадна прерана смрт, тј. нагло прекинут живот, чиме су и евентуални песникови даљи стваралачки планови остали неостварени? Или је његов стваралачки разво интензивирањем рада на упознавању са делом Осипа Мандељштама, чије је дело својеврсним спајањем елемената симболизма и футуризма утемељивало развој водећег тока модерне руске поезије - интересовање за Брјусова потиснуло у други план? О томе сам пре двадесетак година у одељку Дотицаји српске с руском поезијом ХХ века у својој књизи Словенски импулси у српској поезији $X X$ века нешто већ говорио, али, ради ублажавања својеврсног ниподаштавања руског удела у српској култури XX века које су неговали поједини у оно време утицајни историчари српске књижевности, постојећу грађу ваљало би још шире проучити. Надам се да ће то учинити неко од будућих истраживача.

Иако ни сам у једном тренутку није одолео искушењу па је покушао да се упусти у својеврсно програмско дефинисање новог књижевног правца неосимболизма, Бранко Миљковић је, пратећи шта расте и у „другим врлетима“, дужну пажњу посветио још неколиким великим индивидуалним стваралачким појавама руске поезије XX века - Александру Блоку, Андреју Белом, Борису Пастернаку, Владимиру Мајаковском, Осипу Мандељштаму и Леониду Мартинову. И чинио је то директним урањањем у живо уметничко ткиво њихових песама.

Било је логично да се Бранко Миљковић заинтересује за поезију Брјусова као једног од најистакнутијих вођа руског симболизма, који се и у својим есејима бавио поетиком модерне поезије краја XIX - почетка XX века, засноване посебно на познавању дела стваралаца француског језичког подручја (Малармеа, Рембоа, Верлена, Верхарена и др.), чије је стихове такође у то време претакао на српски језик и он сам. Занимљив је Миљковићев избор Брјусовљевих песама чије је преводе објавио у часопису. 
Инсистирајући на томе да његов неосимболизам не треба мешати са сим болизмом, Миљковић истиче: „Симбол је за нас инкарнација стварности, кондензовање стварности у простору и времену у оно што је есенцијално и битно. Остваривање симболичног израза је омогућено унутрашњом дистанцом према стварима, у односу према њима који карактерише нужност и неминовност онога што долази сутра. Потпуно прожимање стварности и њеног суштинског израза, есенцијално повезивање хуманог са оним што је битно у стварима остварује се симболичним речима поезије.“ (Миљковић 1972, књ. 4: 243) И Брјусов је песник који је у другој фази свог стваралачког развоја настојао да своје раније назоре трансформише удаљавањем од екстрема симболистичког мистицизма (његова теза је да је руски симболизам као књижевна школа завршио свој век 1910. године). Таква схватања повукла су га, поред осталог, и ка поетици тзв. научне поезије, коју је, имајући у виду античке узоре, у руској поезији неговао још Ломоносов, а која је крајем XIX - почетком XX века, актуелизована и у француској литератури. У том контексту неговања, како је Миљковић формулисао, „унутрашње дистанце према стварима“, спеване су и Брјусовљеве песме Свет електрона и Свет $N$ димензија.

Погледајмо како је наш песник - у име немистичног „прожимања стварности и њеног суштинског израза“, ради „есенцијалног повезивања хуманог са оним што је битно у стварима... симболичним речима поезије“- - те две песме преточио на српски језик. Ево Брјусовљевих оригинала и Миљковићевих превода:

\section{Мир электрона \\ Свет електрона \\ Быть может, эти электроны \\ Искусства, знанья, войны, тронь \\ И память сорока веков! \\ Еще, быть может, каждый атом - \\ Вселенная, где сто планет; \\ Там - все, что здесь, в объеме сжатом, \\ Но также то, чего здесь нет. \\ Их меры малы, но все та же \\ здесь; \\ Там скорбь и страсть, как здесь, и даже \\ Там та же мировая спесь \\ Их мудрецы, свой мир бескрайный \\ Поставив центром бытия, \\ Спешат проникнуть в искры тайнь \\ И умствуют, как ныне я; \\ А в миг, когда из разрушенья \\ Творятся токи новых сил, \\ Кричат, в мечтах самовнушенья,
Что бог свой светоч загасил! \\ Можда је сваки електро \\ Свет континената пет, \\ Где постоји и знање, и рат, и трон, \\ И четрдесетвековна свест. \\ И атом је, можда, свемир, ето, Који планета сто запрема; \\ Све је као код нас - ал' сажето, \\ А има и чега овде нема. \\ Њихове су мере мале, али Бесконачност је као код нас; \\ И тамо је туга, страст што пали \\ И охолости светске глас. \\ Мудраци им, свој свет бескрајни \\ Узевши за центар склада, \\ Зуре да продру до дна тајни \\ И мудрују као ја сада; \\ Али кад се из разарања \\ Стварају нове струје сила, \\ Да се луч света угасила!}

13 августа 1922
Бранко Миьковић у српској рецепцији поезије Валерија Бррусова

Мир $\mathrm{N}$ измерений

Свет N димензија

Высь, ширь, глубь. Лишь три координаты. Знамо само за три координате.

Мимо них где путь? Засов закрыт.

С Пифагором слушай сфер сонаты, Где је пут мимо? Незнањем је скрит. Атомам дли счет, как Демокрит. Атоме пребрајај као Демокрит.

Путь по числам? - Приведет нас в Рим он (Все пути ума ведут туда!)

. Пут по бројевима? - Води нас у Рим он (И сви путеви ума воде туда!) Та же в зубы узкая узда!

Но живут, живут в $\mathrm{N}$ измереньях Вихри воль, циклоны мыслей, те, $\quad$ Воље и мисли вихор што се врти, С нашим шагом по одной черте!

Наши солнца, звезды, все впространстве, Наша сунца, звезде које небо, расу, Вся безгранность, где и свет бескрыл, Бескрај којим бескрајна светлост сјаји, Лишь фестон в том праздничном убранстве, Само су опрема у празничном украсу Чем их мир свой гордый облик скрыл. $\quad$ Којим свет њихов горди облик таји.

Наше время - им чертеж на плане. Вкось глядя, как мы скользим во тьме, Боги те тщету земных желаний Метят снисходительно в уме.

Наше је време цртеж им на плану, Гледајућ искоса где нам тама прети, Ти богови ништавност свих земаљских жеља

1 января 1924

Из анализе рукописа Миљковићевог превода Облака у панталонама могли смо видети да је у њему доследно поштована основа версификације руског „револуционара у поезији“. Можда је то резултирало из чињенице да је управо оријентација на тонски стих била и једна од компонената новог, модерног (,револуционарног“) односа према класичној силабичко-тонској метрици. Брјусов је, иначе, раније наступао и као поборник слободног стиха, али у овим песмама основ његовог песничког исказа је у оквирима силабичко-тонске версификације: Свет електрона спеван је у јамбу $(5 \% ; 90 \% ; 0 \% ; 80 \% ; 0 \%$ $65 \% ; 0 \% ; 100 \%)$, а Свет $N$ димензија у трохеју $(85 \% ; 15 \% ; 80 \% ; 10 \% ; 75 \% ; 5 \%$; $70 \% ; 0 \%)$. У Миљковићевом преводу Света електрона, ако се, што је иначе уобичајено, изузме почетна стопа и, због природе акцента у српском језику, последња стопа стиха, могло би се наслутити, (да употребимо термин који је користио Кирил Тарановски) неко ,јампско фразирање“ $(75 \% ; 30 \% ; 6,7 \%$; $30 \% ; 25 \% ; 40 \% ; 70 \% ; 20 \%)$. У Миљковићевом преводу Света $N$ димензија трохеј - којим се, за разлику од јамба, с обзиром на природу српског језика могуће лако певати - тешко је и наслутити (распоред акцената у њему изражен у процентима распоређен је овако: $95 \% ; 15 \% ; 45 \% ; 55 \% ; 20 \% ; 40 \% ; 35 \%$; $45 \% 30 \%$ ).

Како се ово може објаснити? Можда би нам за одговор на такво питање могла помоћи једна констатација из Миљковићевог приказа превода Данка Анђелиновића збирке песама Освалда Рамуа Поезија, из 1958. године: „Преводи 
Данка Анђелиновића сачували су све ито не сме бити изгубљено (курзив - М. С.) приликом претакања поезије из једног језика у други“ (Миљковић 1972, књ 4: 80). Она нам даје право на закључак да Миљковић има у виду преводилачки приступ поделе компонената текста оригинала на инваријантне и вариајнтне са становишта њихове функционалне еквивалентности у оквиру конкретног изворника. Тако је важност што потпунијег преношења предметно-мотивске садржине дела које припада научној поезији - овог пута могла да потисне у други план версификацијски аспект песничког исказа (као варијантан).

Додуше, ово потискивање је извршено тако да буде само делимично: изгубило се силабичко-тонско стопно фразирање, али су римовањем и уједначеном схемом распореда рима у оквиру класичне строфике ипак сачуване ознаке класичног везаног исказа. Истовремено, да би се нагласило да је реч о модернизованој тематско-мотивској садржини, у преводу је преточена и изворна, већа концентрација модернизованих, тзв. „непотпуних рима“. Иначе, Миљковић је у Свету електрона у две од пет строфа покушао да сачува и мушку риму у парним стиховима, да би у Свету $N$ димензија од мушких рима и потпуно одустао.

Мора се, међутим, напоменути да је преводилац у последњој строфи Света електрона, као и у трећој и завршној строфи Света $N$ димензија непарне стихове због нечега оставио неримованим. Но ипак је савремен песнички исказ ефектно обележен тиме што су класичне риме, као у оригиналу, прошаране римама попут: пет - свест, туда - узда, Рим он - Риман...

Уколико смо прихватили тезу да је Миљковић у овим преводима, ради отварања ширег простора за представљање (можда и афирмацију?) тематско-мотивске садржине научне поезије, доследно поштовање ритмичко-метричке структуре оригинала доживео као делимично ирелевантно (дакле, варијабилно), дужни смо детаљније да погледамо и оно што би он могао сматрати инваријантним (план тематско-мотивске садржине).

У целини узето, може се рећи да је већина релевантних мотива релативно успешно преточена У Свету електрона пада у очи, рецимо, бриљантна преводилачка трансформација последњег стиха прве строфе којом се, због риме у српском језику, Брјусовљево: „память сорока веков“ (дословно: „памћење из

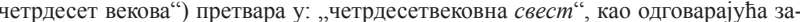
мена, уклопљена у дати контекст. Али велика је штета што је из тог контекста у преводу, уз „знање“ (атрибут науке) изостављена „уметност“ (рус. „искусство“). Нису без мане ни преводилачка решења у закључној строфи песме. Брјусовљево: „А в миг, когда из разрушенья / Творятся токи новых сил“ (досл.: „А у трену, кад из рушења / Настају струје нових сила“), мудраци из других светова: „Кричат, в мечтах самовнушенья, / Что бог свой светоч загасил.“ (досл.: „Вичу, због самоохрабрења / Да је то бог своју лучу угасио“) - у Миљковићевом преводу је преточено као да је реч о новим струјама сила, а не о струјама нових сила, као да вичу из свог уображена а не да би сами себе охрабрили, саопштавајући да се угасила „луч света“, а не да је управо бог угасио своју лучу. Да ли је до ових померања дошло због језичко-преводилачких или из неких других недоумица данас није неопходно нагађати...
У преводу Cвета $N$ димензија без именовања трију координата овоземаљског поимања ствари (висина, ширина и дубина) осиромашена је, али није и потпуно изгубљена тематско-мотивска садржина песме. Брјусовљева поетска теза je, наиме, да се продором даље од тих познатих датих утире пут за спознају мноштва паралелних светова различитих димензија и различитог нивоа цивилизацијског развоја, којом ће човек моћи компетентно да сагледа и своју личну и друштвену егзистенцију. Та теза је очувана успелим преводилачким трансформацијама, посебно, у трећој строфи: „Али живи у $\mathrm{N}$ диманзија, живи / Воље и мисли вихор што се врти, / Коме с детињим знањем смешан сам, Кораком својим све по истој црти!“ У пробијање пута „мимо засова“ (јер је са само три димензије - „засов затворен“) воде нас, како песник наговештава, мудраци од античких научника Демокрита и Питагоре, до научника новог доба попут творца нееуклидовске геометрије Лобачевског (1792-1856), или Бернхарда Римана (1826-1866) - до њихових настављача, Брјусовљевих савременика на челу са Ајнштајном (1879-1959)...

Штета је што наш преводилац, очито, није имао на уму да руска реч „убранство“, осим значења „опрема стана, покућство; украс; коњска опрема“ има и значење „одећа“, и да се руско „фестон“ код нас може превести са „фистан“, или „фустан“, па се претпоследња строфа превода не може сматрати нарочито успелим преводилачким остварењем.

А гледано са данашње дистанце, сви побројани изостављени или померени детаљи са изворном Брјусовљевом конкретизацијом могу пресудно да утичу на проницање и у још који слој значења преведеног уметничког дела. Довољно је ове две песме прочитати у контексту податка да је Cвет $N$ димензија песма која је написана управо на дан, иначе, различито тумачене загонетне Лењинове смрти, па да нас мотив открића Лобачевског да она Еуклидова линија толико већ векова сматрана једино могућом заправо није једина - блесне као упозорење да се треба чувати искључивости у просуђивању; па да нас мотив електрона који су свак за себе паралелни светови различитих димензија са познатим нам, али такође и још незнаним нам мерилима, са $\mathrm{N}$ димензијама, светови чијим смо „вихорима слободе“ и „стрелама мисли вредне... ми с дечијим знањем“ смешни - упути на помисао да су то, можда, већ критичке оцене конкретизације теоријских, уопштених идеја Револуције, да почиње да се разочарава у мирнодопски ток њихове реализације у новој совјетској држави (,пут по бројевима“; „мудраци“ паралелних малих светова из електрона што „журе да проникну у жижу тајни“, при чему свак „свој свет бескрајни / Сматра центром постојања“, при чему је сваки од тих светова пун „туге и страсти“ и сваки, попут овог нашег, носи „исту надменост светску“, јер „наша сунца, звезде, сви ови простори, / Сав тај бескрај, где је и сјај бескрил био / Тек је фистан празничне одоре / Којим је свој облик поносан свет скрио“ - док богови са паралелних светова развијенијих од нашег „пусте жеље нас земљана“ само „снисходљиво.. предају... бележници“).

Овакво тумачење наведених Брјусовљевих песама о којима је реч могло би на први поглед деловати као својеврсно натезање, пошто је Брјусов један од водећих руских симболиста који се у завршном периоду живота декларативно враћао својеврсној, официјелно пожељној, поетици реализма, као и пошто је он 
руски песник, писац уметничке прозе и есејиста који је у постреволуционарној совјетској култури све до смрти био један од водећих реформатора нове књижевне издавачке политике и организатор рада удружења совјетских писаца. Међутим, у данашњој руској науци о књижевности ранији поглед на Брјусовљево књижевно дело почиње да се допуњује, па, у извесној мери, и да се коригује. Као илустрацију за ову тврдњу погледајмо следећу констатацију J. С. Тајлакове из зборника радова са међународног симпозијума, одржаног 2012. године у Перму:

„Феномен Валерија Јаковљевича Брјусова до данашњег времена у руској науци о књижевности из мноштва објективних и субјективних разлога остаје непроучен. $[\ldots]$

Брјусов је у руској историји остао 'протеј' и 'комуниста' иако ни једно ни друго никада није био. На феномен личности у његовом случају не треба гледати из перспективе практичне, материјалне активности, већ из аспекта активности његовог духа и мисли: са сваким својим чланком о новим методима и приступима у интерпретацији текста овај метар (мајстор, учитељ - М. С.) симболизма се несвесно, 'метакултурно', приближавао кругу научника херменеутичара - еклектичном Ф. Шлајермахеру (1768-1834), психофизиологичном В. Дилтеју (1833-1911), феноменологичном Г. Шпету (1879-1937). У размишљању о ситуацијама суживота Ја са другом личношћу био је близак Дилтејевом ученику Буберу (1878-1965). До разраде идеје о комуникативној суштини уметности Брјусов стиже и пре самог Бахтина, до истраживања у области психологије стваралаштва - Л. С. Виготског.“ 1

Било је логично да „неосимболисти“ Миљковићу, који инсистира на томе да се његова поетика разликује од симболистичке и није заснована на мистици (а наши историчари књижевности је карактеришу као својеврстан спој симболизма и надреализма) - кад преводи руске симболисте, буду посебно занимљиве управо оне Брјусовљеве песме у којима је симболистичка религиозна „мистика“ у прототексту замењена темама и мотивима „научне поезије“. Одавно је још констатовано да су у скелету Миљковићеве визије света елементи сигнирани још у античкој филозофији. Тако у инвентивном предговору његовим Сабраним делима из 1972. године Милан Комненић, рецимо истиче:

„Бранко је био уверен да се све може опевати, и научно откриће, и филозофски систем (па и Ајнштајнова теорија релативитета), као што је, у исти мах, сматрао да су песничка искуства у овом веку најпоузданији извори метафизичком мишљењу. [...] Песничку имагинацију хтео је да нахрани космогонијским елементима (водом, ватром, ваздухом и земљом) потајно верујући у космогонијску улогу песништва као духовног рада.“ (Миљковић 1972, књ.1: 62)

Брјусов је још 1909. године објавио чланак Књижевни живот Франиуске Научна поезија у коме је то усмерење дела савремених француских писаца протумачио као тражење излаза из текуће кризе поезије која заправо представља

${ }^{1}$ Превод М. С. из: Тайлакова Е. С. Эстетические принципы В.Я. Брюсова [Текст] // Актуальные проблемы филологии: материалы Междунар. науч. конф. (г. Пермь, октябрь 2012 г.). - Пермь: Меркурий, 2012. — URL https://moluch.ru/conf/phil/archive $/ 28 / 2610$ непрекидно варирање стотинак „одавно познатих тема“, због чега озбиљни мислећи људи престају да је читају. Логика протагониста „научне поезије“, према Брјусову, своди се на следеће:

Поезија треба да осмишљава стварност, да установљује свој однос према сталним законима историје и социологије. Користећи свој метод интуитивне синтезе, поезија може постати најављивачица будућности [...] Снагом стваралачке интуиције песник мора да уочава везе између елемената света и живота, које егзактно знање још није открило, и да наслућује нове путеве за научна остварења. И ако уметност ваља да полази од научних чињеница, наука би требало животворно надахнуће да тражи у уметности...“

Брјусов закључује:

„Наука се путем упоређивања, супротстављања, утврђивања саодноса труди да разлаже саставне елементе света. Уметност путем аналогија жели да их повезује у неке целине. Дакле, наука даје елементе света од којих уметник ствара, тако да уметност почиње тамо где се наука зауставља (курзив - М. С.). То се у потпуности подудара са концепцијом 'научне поезије'. [...] Очито, нова критика одлучно одбацује сва досад позната учења о коначном циљу уметности, укључујући Аристотелову теорију ‘подражавања' (mimesis), Хегелову теорију 'лепоте', шилер-спенсеровску теорију ‘бесциљне игре', сензуалистичку теорију посебног 'естетског задовољства', и теорију 'комуникације' чији је поклоник код нас био Л. Толстој. Тако је рашчишћено поље за утврђивање теорије коју је истакао А. Потебња о уметности као посебном методу сазнања.“

Морамо признати да у Брјусовљевим песмама Свет електрона и Свет $N$ димензија које је Миљковић превео имамо скоро парадигматски пример Комненићевог споја опевања филозофског система, научних открића и „искуства“ песника као мислећег бића из најновијег времена. Тај парадигматски спој лако ћемо пратити и у Миљковићевим оригиналним песмама. На овом месту као пример погледајмо једну која Хераклитове „елементе“ има и у наслову:

Похвала елементима

Док спавам звезде мирим речи одмарам а кад се пробудим не чујем се од мора не видим се од живота ја љубим воду светове одражене нађох ваздух и обрадовах се цвет се претвара у искру полет је насиље ватро кад умрем дореци уђи у реч - ако је јака издржаће напусти прозирност и проговори рекох ваздуху не издај као што ме издала вода 
198

Миодраг Сибиновић

и свет који је продао себе

не дај да те сажму, и искористе твоје знање

претварајући те у формулу без птица

једнога дана припитомићемо ватру

земљу ћемо послати у школу

где предају цветови и лековите траве

ослободићемо воду и учинити је искреном

али данас једна нова варница

удвара се свету и глави

испуњеној сламом.

Милан Комненић сматра да у Миљковићевим песмама у којима је „песник... верујући у космогонијску улогу песништва као духовног реда“, песничку имагинацију „хтео да нахрани космогинијским елементима“ именованим „номиналистичким поступком“ нема неопходне „песничке синтезе“: „Песме настале по овом опредељењу остале су углавном скеле неке будуће градње за коју је било потребно више поетског ткива и више времена него што је Миљковић имао.“ (Миљковић 1972, књ. 1: 62)

Нема сумње у то да је и претакање на српски језик Брјусовљевих песама било део Миљковићевог већ уобичајеног стваралачког трагања за искуствима и из „туђих врлети“. Нема сумње у то да за Хераклита и његовог опонента Демокрита, или за „,атоме“ и могуће „паралелне светове“, као ученик гимназије и студент филозофије није сазнао од Брјусова, али је тачно да је песму Похвала елементима написао у време кад је преводио и ове песме Брјусова. Ми данас можемо само да нагађамо да ли му је то превођење било подстицај за писање Похвале елементима или је превођење и објављивање тих превода у часопису „Сусрети“ 1958. године требало да буде посредна потврда универзалне вредности оваквог тематско-мотивског арсенала самог савременог српског песника. Али уколико се има у виду чињеница да Брјусовљев Свет $N$ димензија има конотацију са евентуалном Стаљиновом ликвидацијом Лењина у борби за врховну партијску и државну власт, Миљковићев мотив издаје воде, мотив света који је продао себе, мотив припитомљавања ватре, уз будуће ослобађање воде после чега ће вода постати искрена - скреће пажњу на загонетну поенту песме Похвала елементима: „али данас једна нова варница / удвара се свету и глави / испуњеној сламом“ (кад на ово указујем, имам у свести и стандардну флоскулу употребљавану у расправама о идеолошкој чистоти из времена кад је Миљковићева песма написана: „опасност од увлачења непријатељских елемената у наше редове“)..

Морамо имати у виду да је Комненић у цитираном предговору констатовао и да Миљковић у својим најбољим песмама превазилази слабости „номиналистичког поступка“, у којима „избегава сувопарне, појмовне, коначно опште и нимало изворне 'максиме и сентенце'“ У таквим песмама је „сасвим уклоњен терет материје, што значи да су све датости добијене перцепцијом и сећањем
Бранко Миъковић у српској речепцији поезије Валерија Брјусова

доживеле дубоко преобликовање на плану песничке слике.“ (Миљковић, књ. 1 : 63) Треба ли трошити речи на доказивање да је управо све то остварено у песми Похвала елементима Бранка Миљковића који је и преводилац песама Валерија Брјусова Свет електрона и Свет $N$ димензија?!

Цитирана литература

Миљковић, Бранко, Сабрана дела. Књ. 1-4. Ниш, Градина, 1972. Стојнић, Мила, Руско-српска књижевна преплитања. Београд, Завет, 1994. Тайлакова Е. С. Эстетические принципы В.Я. Брюсова [Текст] // Актуальные проблемы филологии: материалы Междунар. науч. конф. (г. Пермь, октябрь 2012 г.). — Пермь, Меркурий, 2012. — URL https://moluch.ru/conf/phil/archive/28/2610

\section{Извори}

Миљковић, Бранко, Сабрана дела. Књ. 1-4. Ниш, Градина, 1972.

Брјусов, Валериј, Me eum esse. Крушевац, Багдала, MCMLVIII

Брјусов, Валериј, Духови ватре. Ниш, Градина, 1989.

Брјусов Валриј, Огледало сенки. Београд, Удружење издавача и књижара, 2000.

Брюсов, В. Я., Собрание сочинений в семи томах. Т. 1-7. Москва, Художественная литература, 1975.

Литературное наследство. Валерий Брюсов. Москва, Издательство «Наука», 1976. Модерна руска поезија. Београд, Нолит, 1961.

Модерно светско песништво. Т. І. Београд, Просвета, 1983

Миодраг Сибинович

БРАНКО МИЛЬКОВИЧ В КОНТЕКСТЕ СЕРБСКОЙ РЕЦЕПЦИИ ПОЭЗИИ В. Ю. БРЮСОВА

Резюме

Переводы стихов В. Я. Брюсова на сербский язык, выполненные Бранко Мильковичем, являются серьезным началом рецепции поэзии этого русского поэта в сербской перевоявляются серьезным началом рецепции поэзии этого русского поэта в сербской перево48 стихотворений Брюсова, но с 1959 до своей внезапной смерти он опубликовал всего де48 слихонворений Брюсова, но с 1959 до свосй внезики смерли он опубликовал всего девять своих перевдов. Остальные найдены в его рукописном архиве и напечатаны в четырехтомном издании Собрания сочинении Б. Мильковича, вышедшем в 1972 году, а также книге поэзии Брюсова Духови ватре («Градина», Ниш, 1989). Автор статьи считает, что, возможно, меньший интерес читателей и издателей к поэзии Брюсова связан и с внехудожественными факторами: в отличие от Пастернака, Хлебникова и Мандельштама, которых печатали в эти годы в переводе на сербский, Брюсова нельзя было приобщить к жертвам сталинизма.

Славистика XXIII/1 (2019) 
Переводы Б. Мильковича являются в основном удачными воплощениями подлинников Брюсова. Некоторые из них включались и в сербские антологии современной русской, равно как и европейской, поэзии.

На примере стихотворения Б. Мильковича Похвала елементима, рассматриваемого в контексте стихотворений Брюсова Мир электронов и Мир $N$ димензий, автор статьи показывает, что интертекстуальный анализ свидетельствует о возможности своеобразной переклички сербского неосимволиста Мильковича с русским символистом Брюсовым.

Ключевые слова: русская литература, сербская литература, сербско-русские литературные и культурологические связи, художественный перевод, интертекст. 